FORAMS 2006

\title{
Divergence of late Miocene Caribbean and tropical Eastern Pacific shallow-water benthic foraminifera
}

\author{
Laurel S. Collins \\ Department of Earth Sciences, Florida International University, Miami, Florida, 33199, U.S.A. \\ collinsl@fiu.edu
}

In the Paleogene to earliest Neogene, benthic foraminiferal and molluscan faunas from the Caribbean and Eastern Pacific were reported to be quite similar, because a tropical seaway connected the two oceans across the area that is today southern Central America. About four million years ago the Central American Seaway closed completely, and today the two faunas are quite different in composition. This study compares Neogene benthic foraminiferal faunas of formations from either side of the Central American isthmus that are from the same time intervals and paleobathymetric zones, to look at changes in faunal composition, diversity and the proportion of endemism up through the time of seaway constriction and complete closure.

Formations on the Caribbean side of Central America are from the Limón Basin of Costa Rica, and the Bocas del Toro Basin and Panama Canal Basin of Panama. The time period covered by these formations is from early Miocene to late Pliocene, and from middle neritic to lower bathyal water depths. Because there are no comparable, well-oxygenated Neogene depositional basins on the Pacific coast of Central America, benthic foraminiferal assemblages primarily from formations of coastal Ecuador are used for comparison with the Caribbean formations. Ecuador was the furthest that tropical waters extended south on the Pacific side of Central America, just north of stronger influence by the Peru Current. The time interval covered by Ecuador formations is also early Miocene to late Pliocene, from middle neritic to lower bathyal depths.

The prediction, based on preliminary results, is that species distributions should indicate a stage of developing endemism in late Miocene Caribbean and Pacific faunas. For example, the deeper, outer neritic faunas of the late Miocene Angostura Formation of the Borbón Basin, northwestern Ecuador, show less similarity with the Caribbean than do the shallower, middle neritic faunas of the same formation. Deeper faunas should have been affected first by the rise of the sill that severed the connection between Caribbean and tropical Eastern Pacific faunas. Diversity is also predicted to have been more similar between the Caribbean and tropical Eastern Pacific prior to seaway constriction, and to have diverged in the late Miocene to early Pliocene. 